\title{
EFFECTS OF N, PAND K FERTILIZERS ON EDIBLE AMARANTH (Amaranthus spp.) GROWN ON THE RED SOIL OF OKINAWA
}

\author{
AKAMINE, H. - OHSHIRO, M. - HoSSAIN, M. A.* \\ Faculty of Agriculture, University of the Ryukyus, Okinawa 903-0213, Japan \\ *Corresponding author \\ e-mail:amzad@agr.u-ryukyu.ac.jp; phone: +81-98-895-8824 \\ (Received $19^{\text {th }}$ Dec 2020; accepted $18^{\text {th }}$ Mar 2021)
}

\begin{abstract}
Fertilizer regimes were evaluated on edible amaranths to understand fertilizer management on the red soil ( $\mathrm{pH}$ 5.1) of Okinawa. Effects of fertilizers 0 (Control), N, P, K, N+P (NP), N+K (NK), P+K (PK) and $\mathrm{N}+\mathrm{P}+\mathrm{K}(\mathrm{NPK})$ were evaluated on red leaf amaranth in two experiments. Each of the $\mathrm{N}, \mathrm{P}$ and $\mathrm{K}$ fertilizers was applied at $50 \mathrm{~g} \mathrm{~m}^{-2}$. In addition, the effects of NPK (N:P:K=1:1:1) fertilizer at $0,10,20,30$ and $40 \mathrm{~g} \mathrm{~m}^{-2}$ were evaluated on red stem amaranth and red leaf amaranth. Growth and yield of amaranth cultivated under N, P, K, NK and PK treatments were very poor, but significantly higher with the NPK followed by NP. Growth parameters and yield greatly increased with the NPK fertilizer at $30-40 \mathrm{~g} \mathrm{~m}^{-2}$ for red stem amaranth and 20-30 $\mathrm{g} \mathrm{m}^{-2}$ for red leaf amaranth. Mineral contents in the amaranths did not clearly differ with the different fertilizers. Mineral contents were higher or same in the amaranths cultivated with the fertilizer NPK at $30-40 \mathrm{~g} \mathrm{~m}^{-2}$, compared to those under control treatments. The results indicate that combined fertilizer NPK at $30-40 \mathrm{~g} \mathrm{~m}^{-2}$ is effective for higher yield and quality of amaranth in the red soil.
\end{abstract}

Keywords: acidic soil, growth characteristics, minerals, nutritive-value, tropical vegetable

\section{Introduction}

Different plant species respond differently to soil nutrient status, and fertilizer rates and combination (Hossain and Ishimine, 2005; Akamine et al., 2007; Chowdhury et al., 2008; Hossain et al., 2011). Balanced fertilizer is effective to sustain soil fertility, and growth, yield and quality of a plant species (Hossain et al., 2004; Akamine et al., 2007; Chowdhury et al., 2008; Shimray et al., 2019). The major nutrients N, P and K individually or together maintain growth, yield and quality of plants (Ivonyi et al., 1997; Nakano and Morita, 2009; Skwaryo-Bednarz et al., 2011; Hossain et al., 2012). Nitrogen, the principal element of chlorophyll, influences photosynthetic efficiency, which contributes to 26-41\% of crop yield (Maier et al., 1994; Ivonyi et al., 1997). Potassium regulates activities of minerals and promotes $\mathrm{N}$ uptake efficiency of plants. Insufficient $\mathrm{K}$ causes shoot yellowing and low resistance to cold and drought in plants (Oya, 1972). Phosphorus enhances absorption of other nutrients and promotes plant growth when applied with other fertilizers (Akamine et al., 2007).

Amaranthus is a promising food crop for its resistance to heat, drought, diseases and pests, as well as high nutritional value (Sreelathakumary and Peter, 1993; Rastogi and Shukla, 2013; Longato et al., 2017; Maurya and Arya, 2018; Soriano-García et al., 2018). Several Amaranthus species are popularly cultivated as vegetable and grain in Africa, Bangladesh, Caribbean, China, Greece, India, Nepal and South Pacific Islands (Prakash and Pal, 1991; Stallknecht and Schulz-Schaeffer, 1993; Svirskis, 2003; Dewan et al., 2017). Vegetable amaranth, superior in taste to spinach (Spinacia oleracea), possesses higher carotenoids (90-200 $\mathrm{mg} \mathrm{kg}^{-1}$ ), protein (14-30\%), carbohydrate 
(5.0 $\left.100 \mathrm{~g}^{-1}\right)$, fat $\left(0.1 \mathrm{~g} 100 \mathrm{~g}^{-1}\right)$, calories (43 Kcal $\left.100 \mathrm{~g}^{-1}\right)$ and ascorbic acid (28 mg $100 \mathrm{~g}^{-1}$ ) (Abbott and Campbell, 1982; Prakash and Pal, 1991; Shittu et al., 2006; Dewan et al., 2017). Amartanthus possesses antioxidant, antimalarial and antiviral properties, which prevent cancer, cardiovascular diseases, diabetes, etc. (Dasgupta and De, 2007; Khandaker et al., 2008; Shukla et al., 2010; Adegbola et al., 2020).

Amaranthus grows very fast in tropical and subtropical regions under different agroclimatic and edaphic conditions (Singh and Whitehead, 1996; Dewan et al., 2017). In Okinawa, some amaranth species are found as weed in different soils (Hossain and Ishimine, 2005; Ohshiro et al., 2015). Some edible amaranth lines have been selected as summer vegetables in Okinawa (Ohshiro et al., 2015). Shittu et al. (2006) reported that balanced fertilizer is required to sustain higher yield and nutrients of amaranth in a specific soil.

Soil types and fertilizer regimes were evaluated on growth, yield, and quality of some Amaranthus lines in our previous study (Ohshiro et al., 2016). We have also evaluated fertilizer $\mathrm{N}$ levels and combined fertilizer NPK on amaranth in three major soil types, gray soil, dark-red soil and red soil of Okinawa. Gray soil was best for higher growth and yield of amaranths, and $\mathrm{N}$ fertilizer applied alone increased growth and yield in gray soil but not in dark red soil and red soil. On the other hand, combined fertilizer NPK resulted in the highest growth parameters and yield of amaranths in all soils. Previous studies evaluated fertilizer management strategies for amaranth cultivation on gray soil and dark-red soil (Ohshiro et al., 2016; Akamine et al., 2020). Gray soil covers only $5 \%$ of land, whereas dark-red soil covers $35 \%$ and red soil covers $60 \%$ in Okinawa (Hossain and Ishimine, 2005). In addition, we did not evaluate the effects of separate and combined application of N, P and K on the amaranths in red soil. Therefore, the objectives of this study were to (i) identify the effect of different fertilizer elements and (ii) evaluate rates of combined fertilizer on growth, yield and quality of edible amaranth lines to understand fertilizer management practices in red soil of Okinawa.

\section{Materials and methods}

\section{Soil collection}

Red soil (Ultisol, Kunigami mahji) was collected from the top $50 \mathrm{~cm}$ layer of a field in Nago city, Okinawa. The soil $\mathrm{pH}$ was 5.1 , and the soil contained $0.06 \%$ total $\mathrm{N}$ and $0.20 \%$ total C. Sodium ( $\mathrm{Na}$ ), K, Ca, Mg, Al, Fe, P and Mn contents in soil were 0.69, $0.93,14.51,1.64,0.04,0.25,0.28$ and $0.02 \mathrm{mg} \mathrm{kg}^{-1}$, respectively. Coarse sand, fine sand, silt, clay, and apparent density were $16.92 \%, 20.44 \%, 26.62 \%, 30.92 \%$, and $0.92 \mathrm{~g} \mathrm{~cm}^{-3}$, respectively.

\section{Amaranth lines}

Edible red stem amaranth (BB line) and red leaf amaranth (BC line) of Amaranthus tricolor selected as higher yield and quality in our previous studies (experiments conducted from April, 2010 to May, 2011) were evaluated in this study (Ohshiro et al., 2015). 


\section{Experiment 1: Effects of $N, P$ and $K$ fertilizers applied alone and in combination on amaranth cultivated during November 5 to December 15, 2014}

A glasshouse experiment was conducted at the Subtropical Field Science Center of the University of the Ryukyus, from November 5 to December 15, 2014. The experiment was consisted of eight treatments with five replications (planters). The fertilizer treatments were control (Cont), N, P, K, N plus $\mathrm{P}$ (NP), N plus K (NK), P plus $\mathrm{K}(\mathrm{PK})$ and $\mathrm{N}$ plus $\mathrm{P}$ plus $\mathrm{K}(\mathrm{NPK})$. Each of the $\mathrm{N}, \mathrm{P}$ and $\mathrm{K}$ fertilizers at $50 \mathrm{~g} \mathrm{~m}^{-2}(5.0 \mathrm{~g}$ per planter) was mixed with $13 \mathrm{~kg}$ of air dried soil per planter (size $65 \mathrm{E} ; 0.1 \mathrm{~m}^{2}$ ) prior to the seed sowing according to the treatment design. Seed of red leaf amaranth was sown on the soil surface and covered with $0.5 \mathrm{~cm}$ soil layer. The planters were placed randomly, and the plants were thinned to the 8 healthiest stands per planter at 2- to 3-leaf stage. Water was applied as required (considering soil moisture checked by squeezing the soil sample firmly in hand to form an irregularly shaped "ball", plant size and growth stage, daily weather condition, etc.) every day for proper seedling emergence and plant growth. All the windows were kept open to maintain outdoor conditions (light, temperature, humidity) in the glasshouse during the experiment, except typhoon and rainy days.

\section{Experiment 2: Effects of $N, P$ and $K$ fertilizers applied alone and in combination on amaranth cultivated during February 19 to April 4, 2015}

Experiment 1 was repeated to reconfirm the effects of the fertilizers on the amaranth in the same glasshouse from February 19 to April 19, 2015. The experiment was consisted of eight treatments with five replications (planters). The same amaranth line, planter, treatments, fertilizer rates, seed sowing and management practices applied in the experiment 1 were taken in this experiment.

\section{Experiment 3: Effects of NPK fertilizer rates on amaranth cultivated during June 20 to July 24, 2014}

This experiment was conducted in the same glasshouse from June 20 to July 24, 2014. Each experiment was consisted of five treatments with four replications (planters). The fertilizer treatments of $0 \mathrm{~g} \mathrm{~m}^{-2}$ (Control, $0 \mathrm{~g}$ planter-1), $10 \mathrm{~g} \mathrm{~m}^{-2}$ $\left(1 \mathrm{~g}_{\text {planter }}^{-1}\right), 20 \mathrm{~g} \mathrm{~m}^{-2}\left(2 \mathrm{~g}\right.$ planter $\left.^{-1}\right), 30 \mathrm{~g} \mathrm{~m}^{-2}\left(3 \mathrm{~g}_{\text {planter }}^{-1}\right)$ and $40 \mathrm{~g} \mathrm{~m}^{-2}$ $\left(4 \mathrm{~g}\right.$ planter $\left.{ }^{-1}\right)$ were taken. The fertilizers of $\mathrm{N}\left(\mathrm{CO}\left(\mathrm{NH}_{2}\right)_{2}\right), \mathrm{P}_{2} \mathrm{O}_{5}\left(\mathrm{CaH}_{4}\left(\mathrm{PO}_{4}\right)_{2} \mathrm{H}_{2} \mathrm{O}\right)$ and $\mathrm{K}_{2} \mathrm{O}(\mathrm{KCl})$ were applied at the ratio of $\mathrm{N}: \mathrm{P}: \mathrm{K}=1: 1: 1$. The fertilizers were mixed with $13 \mathrm{~kg}$ air dried soil per planter (size 65E) prior to the seed sowing according to the treatments. Seeds of red stem amaranth (BB line) and red leaf amaranth (BC line) were sown on the soil surface and covered with $0.5 \mathrm{~cm}$ soil layer. The planters were placed randomly, and the plants were thinned to the 10 healthiest stands per planter at 2- to 3-leaf stage. Water was applied as required every day for proper seedling emergence and plant growth.

\section{Data collection}

In the experiment 1, five plants were harvested at 40-day after seed sowing (DAS) from each planter, and plant height, stem diameter, leaf number, largest leaf area, total leaf area, and fresh and dry weights of leaf, stem and shoot (leaf+stem is called yield) were determined. In the experiment 2, plant height and leaf number were measured 6 times at a five-day interval strating from 23 DAS, and five plants were harvested from 
each planter at 44 DAS and similar data parameters were measured. In the experiment 3, five plants were harvested from each planter at 35 DAS, and similar data parameters were measured. Stem diameter was measured at $5 \mathrm{~cm}$ from the soil surface.

Determination of leaf area, dry weight, mineral, nitrogen, carbon, soil $p H$ and nutrients

Leaf area was measured with an automatic area meter (AAM-8, Hayashi Denkoh Co. Ltd.). Various parts of amaranth plants were dried at $60{ }^{\circ} \mathrm{C}$ for $48 \mathrm{~h}$ for chemical analysis, and at $80{ }^{\circ} \mathrm{C}$ for dry weight measurement using forced convection oven (DRLF23WA, Advantec). Soil samples were dried at room temperature of $25-28{ }^{\circ} \mathrm{C}$ for 5 days. The plant parts and soil were ground finely for chemical analysis. Mineral contents of soil and nutrients of amaranth were determined with Inductively Coupled Plasma Spectrometer (ICPS-8100, Shimadzu Co. Ltd.). Total C and N were determined with Gas Chromatograph (Soil GS-8A, Shimadzu Co. Ltd., NC-220F Juka analysis center) and Sumigraph (NC-90A, Shimadzu Co. Ltd.). Soil pH was determined with TOA pH meter (HM-20S, Toa Electronic Ltd.).

\section{Statistical analysis}

Average data for each replication was calculated, and then mean and standard deviation (SD) of the replications were determined using analysis of variance. Fishers protected least significant difference (LSD) test at the $5 \%$ level was used to compare treatment means. The amaranth lines were analysed separately.

\section{Results}

\section{Effects of fertilizer $N, P$ and $K$ applied alone and in combination on growth and yield of amaranth line $B C$}

Effects of fertilizer N, P and K applied alone and in combination on growth, plant height and leaf number of amaranth line BC cultivated from November 5 to December 15, 2014 are shown in the Figs. 1 and 2. The plants with the fertilizer $\mathrm{N}$ and NK grew for some days but did not survive finally. Growth of the plants with the fertilizer K, P and PK was very poor, and many of plants died. The growth of amaranth was best with the fertilizer NPK followed by NP.

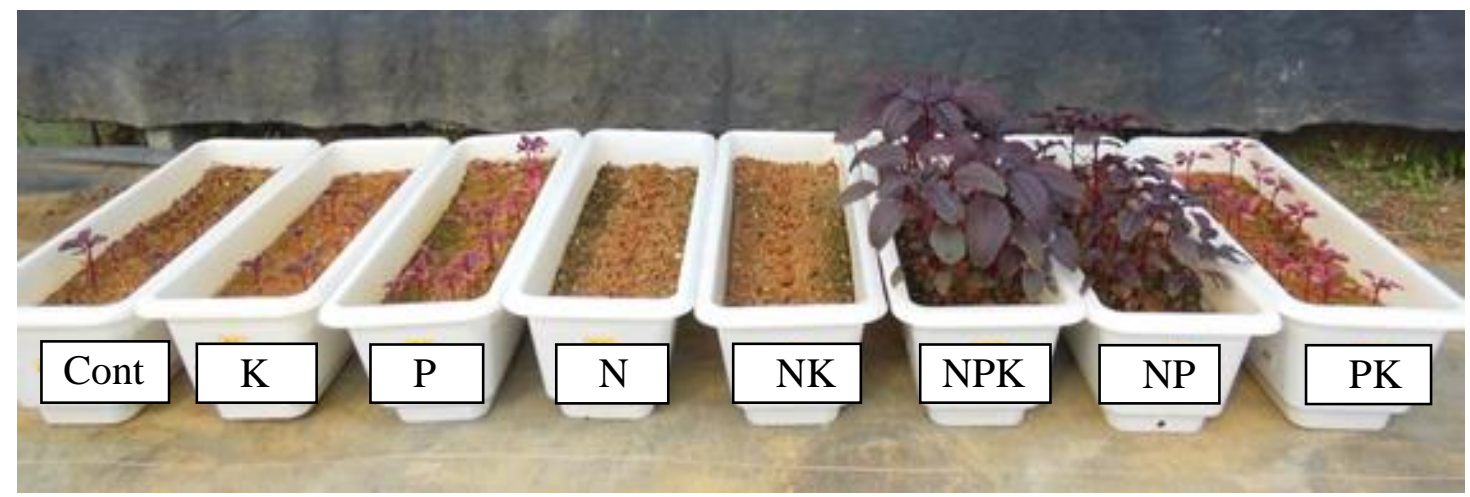

Figure 1. Effects of fertilizer $N, P$ and $K$ applied alone or in combination on growth of amaranth line BC cultivated from November 5 to December 15, 2014 
Plant height was the highest with the combined fertilizer of NPK, which was 3.6 times higher than that with the control treatment (Fig. 2). The fertilizer $\mathrm{N}$ and NK showed adverse effect on plant height. The other fertilizer treatments resulted in increased plant height. The fertilizer NP resulted in the second highest plant height. Plant height with the NPK was about two times higher than the plant with NP (Fig. 2).
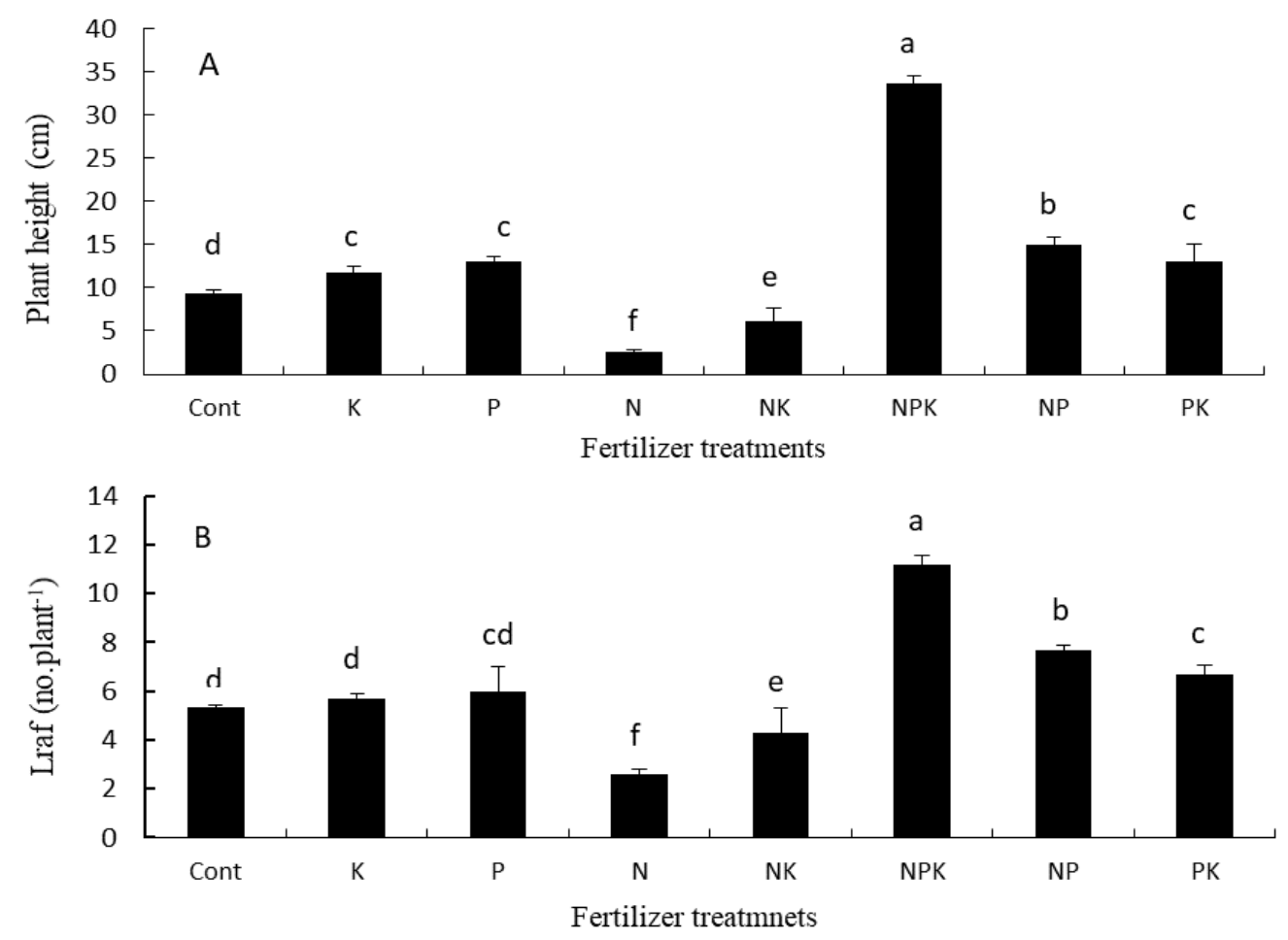

Figure 2. Effects of fertilizer $N, P$ and $K$ applied alone or in combination on plant height (A) and leaf number (B) of amaranth line BC cultivated from November to December, 2014. Bars with the same letter are not significantly different at the 5\% level, as determined by LSD test. Error bars represent standard deviation of the data

The plant with the fertilizer NPK had highest leaf number (11) followed by the fertilizer NP (8) (Fig. 2). The fertilizer K and P applied alone did not result increased leaves per plant. The plant cultivated with the fertilizer $\mathrm{N}$ and $\mathrm{NK}$ resulted in the decreased number of leaves as compared with the control plant.

Data were not recorded for the fertilizers $\mathrm{N}$ and NK due to very poor plant growth. Stem diameter, largest leaf area, total leaf area, fresh leaf and dry leaf of amaranth were increased with the fertilizers NPK and NP (Table 1). Fresh and dry weight of stem and shoot (yield) were highest with the fertilizers NPK followed by NP. The fertilizers K, P and PK did not increase the growth parameters and yield of the amaranth. All the growth parameters and yield were highest with the fertilizer NPK followed by NP.

Plant height and leaf number of amaranth BC line cultivated from February 19 to April 4, 2015 under different fertilizers are shown in the Fig. 3. Plant height and leaf number (Fig. 3) were highest with the fertilizer NPK followed by NP. The leaf number was 11, 9 and 6 with the fertilizer NPK, NP and NK, respectively. The other fertilizer treatments did not show positive effect on plant height. The fertilizers $\mathrm{P}$ and PK showed somewhat positive effect on leaf number. 
Table 1. Effects of fertilizer $N, P$ and $K$ applied alone or in combination on growth parameters and yield of amaranth cultivated from November to December, 2014

\begin{tabular}{|c|c|c|c|c|c|c|c|c|c|}
\hline $\begin{array}{l}\text { Fertilizer } \\
\text { treatment }\end{array}$ & $\begin{array}{c}\text { Stem } \\
\text { diameter } \\
(\mathrm{mm})\end{array}$ & $\begin{array}{c}\text { Largest } \\
\text { leaf area } \\
\left(\mathrm{cm}^{2}\right)\end{array}$ & $\begin{array}{c}\begin{array}{c}\text { Total } \\
\text { leaf area }\end{array} \\
\left(\mathrm{cm}^{2}\right)\end{array}$ & $\begin{array}{c}\text { Fresh } \\
\text { leaf } \\
\text { weight } \\
\text { (g/plant) }\end{array}$ & $\begin{array}{c}\text { Dry leaf } \\
\text { weight } \\
\text { (g /plant })\end{array}$ & $\begin{array}{c}\text { Fresh } \\
\text { stem } \\
\text { weight }\end{array}$ & $\begin{array}{c}\text { Dry stem } \\
\text { weight } \\
\text { (g /plant) }\end{array}$ & $\begin{array}{c}\text { Fresh } \\
\text { shoot } \\
\text { weight } \\
\text { (g/plant) }\end{array}$ & $\begin{array}{c}\text { Dry } \\
\text { shoot } \\
\text { weight } \\
\text { (g/plant) }\end{array}$ \\
\hline Cont & $1.698 \mathrm{c}$ & $2.325 c$ & $6.535 c$ & $1.456 \mathrm{c}$ & $0.120 \mathrm{c}$ & $0.602 c$ & $0.066 \mathrm{c}$ & $2.058 \mathrm{c}$ & $0.186 \mathrm{c}$ \\
\hline $\mathrm{K}$ & $1.750 \mathrm{c}$ & $1.993 \mathrm{c}$ & $6.675 c$ & $1.496 \mathrm{c}$ & $0.210 \mathrm{c}$ & $0.734 \mathrm{c}$ & $0.048 \mathrm{c}$ & $2.230 \mathrm{c}$ & $0.258 \mathrm{c}$ \\
\hline $\mathrm{P}$ & $2.025 \mathrm{c}$ & $2.743 c$ & $7.873 c$ & $1.887 \mathrm{c}$ & $0.287 \mathrm{c}$ & $1.065 \mathrm{~b}$ & $0.085 \mathrm{c}$ & $2.952 \mathrm{c}$ & $0.372 \mathrm{c}$ \\
\hline $\mathrm{N}$ & - & - & - & - & - & - & - & - & - \\
\hline NK & - & - & - & - & - & - & - & - & - \\
\hline NPK & $6.593 a$ & $26.760 a$ & $130.238 \mathrm{a}$ & $15.561 \mathrm{a}$ & $1.775 \mathrm{a}$ & $17.566 \mathrm{a}$ & $0.907 \mathrm{a}$ & $33.127 \mathrm{a}$ & $2.682 \mathrm{a}$ \\
\hline NP & $3.330 \mathrm{~b}$ & $11.250 \mathrm{~b}$ & $45.983 b$ & $4.998 b$ & $0.685 b$ & $2.659 \mathrm{~b}$ & $0.240 \mathrm{~b}$ & $7.657 \mathrm{~b}$ & $0.925 b$ \\
\hline PK & $2.393 \mathrm{c}$ & $5.486 c$ & $13.515 \mathrm{c}$ & $1.660 \mathrm{c}$ & $0.229 \mathrm{c}$ & $1.689 \mathrm{~b}$ & $0.211 b$ & $3.349 b c$ & $0.440 \mathrm{c}$ \\
\hline
\end{tabular}

Data with the same letter within each column for each applied fertilizer are not significantly different at the $5 \%$ level, as determined by LSD test. - data not recorded due to poor growth
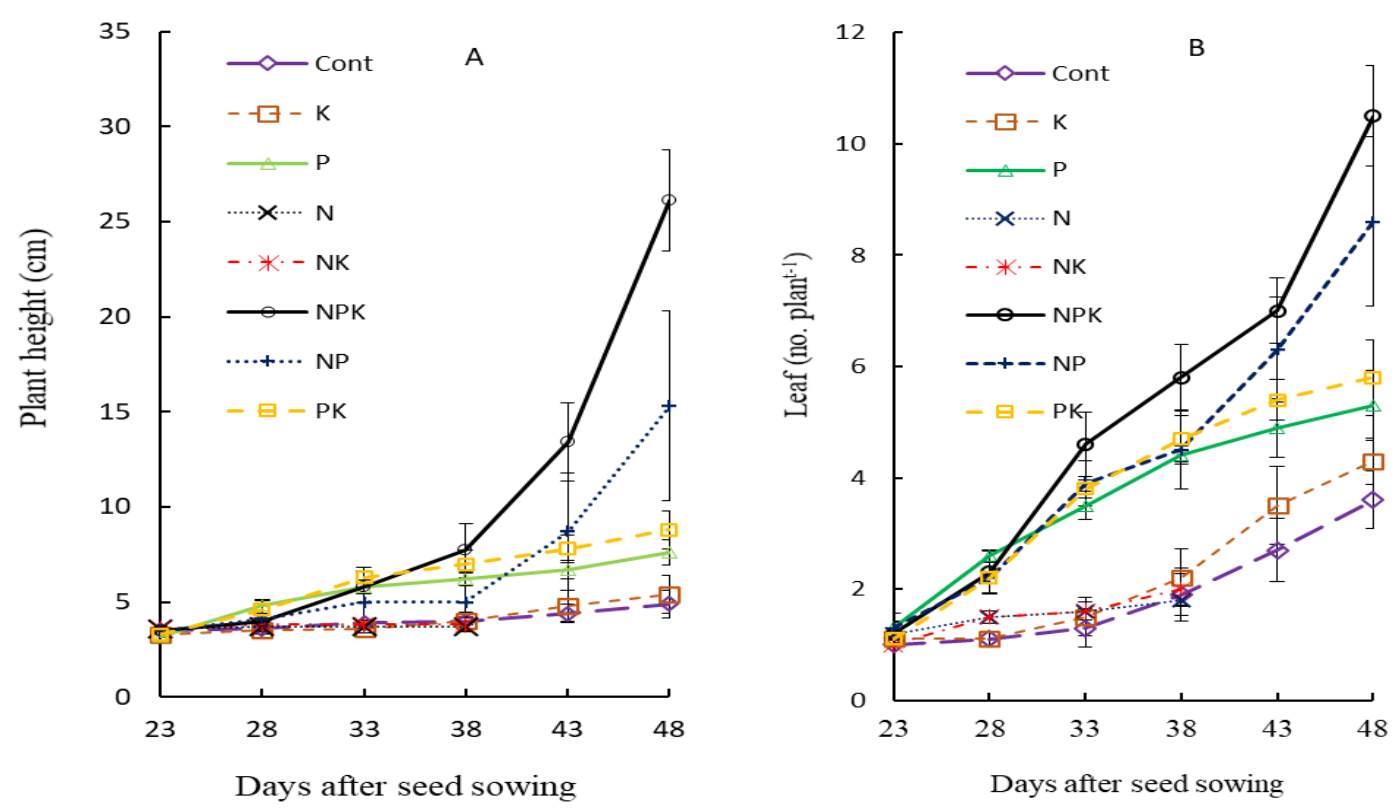

Figure 3. Effects of fertilizer $N, P$ and $K$ applied alone or in combination on plant height and leaf number of amaranth line BC cultivated from February to April, 2015. Error bars represent standard deviation of the data

Growth parameters and yield of amaranth line BC were not measured due to very poor growth (Table 2). Stem diameter and largest leaf area were highest with the fertilizer NPK followed by NP (Table 2). Total leaf area, fresh leaf and dry leaf increased with only NPK. Fresh and dry weights of stem and shoot were highest with the fertilizer NPK followed by NP (Table 2). Most of the growth parameters and yield (shoot) were highest with the fertilizer NPK followed by NP (Table 2). 
Table 2. Effects of fertilizer $N, P$ and $K$ applied alone or in combination on growth parameters and shoot (yield) of amaranth cultivated from February to April, 2015

\begin{tabular}{c|c|c|c|c|c|c|c|c|c}
\hline $\begin{array}{c}\text { Fertilizer } \\
\text { treatment }\end{array}$ & $\begin{array}{c}\text { Stem } \\
\text { diameter }\end{array}$ & $\begin{array}{c}\text { Largest } \\
\text { leaf } \\
\text { area } \\
(\mathrm{mm})\end{array}$ & $\begin{array}{c}\text { Total } \\
\text { leaf area } \\
\left(\mathrm{cm}^{2}\right)\end{array}$ & $\begin{array}{c}\text { Fresh leaf } \\
\text { weight } \\
\left(\mathrm{cm}^{2}\right)\end{array}$ & $\begin{array}{c}\text { Dry leaf } \\
\text { weight }\end{array}$ & $\begin{array}{c}\text { Fresh } \\
\text { stem } \\
\text { weight }\end{array}$ & $\begin{array}{c}\text { Dry stem } \\
\text { weight }\end{array}$ & $\begin{array}{c}\text { Fresh } \\
\text { shoot } \\
\text { weight }\end{array}$ & $\begin{array}{c}\text { Dry shoot } \\
\text { weight }\end{array}$ \\
\hline Cont & $1.880 \mathrm{c}$ & $6.807 \mathrm{~b}$ & $19.350 \mathrm{~b}$ & $1.456 \mathrm{~b}$ & $0.233 \mathrm{~b}$ & $0.602 \mathrm{c}$ & $0.066 \mathrm{c}$ & $2.058 \mathrm{~b}$ & $0.299 \mathrm{c}$ \\
$(\mathrm{g} / \mathrm{n} t)$ & $\mathrm{g} / \mathrm{plant})$ & $\mathrm{g} / \mathrm{plant})$ & $(\mathrm{g} / \mathrm{plant})$ \\
$\mathrm{K}$ & $1.946 \mathrm{c}$ & $3.973 \mathrm{c}$ & $13.680 \mathrm{~b}$ & $1.496 \mathrm{~b}$ & $0.210 \mathrm{c}$ & $0.734 \mathrm{c}$ & $0.058 \mathrm{c}$ & $2.230 \mathrm{~b}$ & $0.268 \mathrm{c}$ \\
$\mathrm{P}$ & $2.120 \mathrm{~b}$ & $6.073 \mathrm{~b}$ & $17.893 \mathrm{~b}$ & $1.887 \mathrm{~b}$ & $0.287 \mathrm{~b}$ & $1.065 \mathrm{~b}$ & $0.148 \mathrm{~b}$ & $2.952 \mathrm{~b}$ & $0.436 \mathrm{~b}$ \\
$\mathrm{~N}$ & - & - & - & - & - & - & - & - & - \\
$\mathrm{NK}$ & - & - & - & - & - & - & - & - & - \\
$\mathrm{NPK}$ & $6.748 \mathrm{a}$ & $34.893 \mathrm{a}$ & $147.510 \mathrm{a}$ & $15.561 \mathrm{a}$ & $1.773 \mathrm{a}$ & $17.566 \mathrm{a}$ & $0.907 \mathrm{a}$ & $33.127 \mathrm{a}$ & $2.682 \mathrm{a}$ \\
$\mathrm{NP}$ & $2.705 \mathrm{~b}$ & $7.518 \mathrm{~b}$ & $32.610 \mathrm{~b}$ & $3.066 \mathrm{~b}$ & $0.403 \mathrm{~b}$ & $1.689 \mathrm{~b}$ & $0.211 \mathrm{~b}$ & $4.755 \mathrm{~b}$ & $0.615 \mathrm{~b}$ \\
$\mathrm{PK}$ & $2.331 \mathrm{~b}$ & $4.711 \mathrm{c}$ & $8.953 \mathrm{c}$ & $0.413 \mathrm{c}$ & $0.201 \mathrm{c}$ & $0.202 \mathrm{~d}$ & $0.120 \mathrm{~b}$ & $0.615 \mathrm{c}$ & $0.321 \mathrm{c}$ \\
\hline
\end{tabular}

Data with the same letter within each column for each applied fertilizer are not significantly different at the $5 \%$ level, as determined by LSD test. - data not recorded due to poor growth

\section{Effects of NPK fertilizer rates on growth and yield of amaranth $B B$ and $B C$ lines}

Growth of amaranth BB and BC lines cultivated in red soil is shown in the Fig. 4. The growth of amaranth $\mathrm{BB}$ line was better with the increasing fertilizer rates. However, the growth was similarly higher with the fertilizers 30 and $40 \mathrm{~g} \mathrm{~m}^{-2}$. The growth of amaranth BC line increased with the increasing fertilizer rates up to $30 \mathrm{~g} \mathrm{~m}^{-2}$, and the growth was found to be lower with the fertilizer $40 \mathrm{~g} \mathrm{~m}^{-2}$ than with the $30 \mathrm{~g} \mathrm{~m}^{-2}$. The plant grown without fertilizer was very poor in both the amaranth lines.
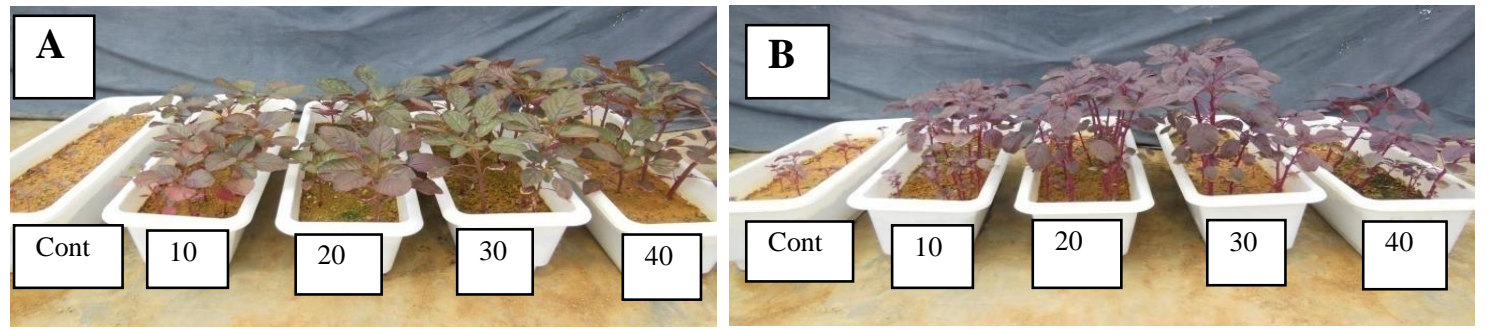

Figure 4. Effects of combined fertilizer NPK rates on growth of amaranth lines $B B(A)$ and $B C$ (B) cultivated from June to July, 2014 in red soil. Cont $(0 \mathrm{~g}), 10\left(10 \mathrm{~g} \mathrm{~m}^{-2}\right), 20\left(20 \mathrm{~g} \mathrm{~m}^{-2}\right), 30$ $\left(30 \mathrm{~g} \mathrm{~m}^{-2}\right), 40\left(40 \mathrm{~g} \mathrm{~m}^{-2}\right)$

Plants height of the amaranth BB line increased similarly with all the fertilizer rates, however the plant height was highest with the $40 \mathrm{~g} \mathrm{~m}^{-2}$ followed by $30 \mathrm{~g} \mathrm{~m}^{-2}$ (Fig. 5). On the other hand, plants height of the amaranth line $\mathrm{BC}$ increased with all the fertilizer rates, and the plant height was similarly highest with the 30 and $40 \mathrm{~g} \mathrm{~m}^{-2}$ (Fig. 5).

The leaf number of BB line increased with all the fertilizer rates, which was similarly highest with the fertilizer rate of 30 and $40 \mathrm{~g} \mathrm{~m}^{-2}$ (Fig. 6). The BC line obtained similarly higher leaf number with all the fertilizer rates, however the leaf number was found to be highest with the fertilizer 20 and $30 \mathrm{~g} \mathrm{~m}^{-2}$ (Fig. O). 

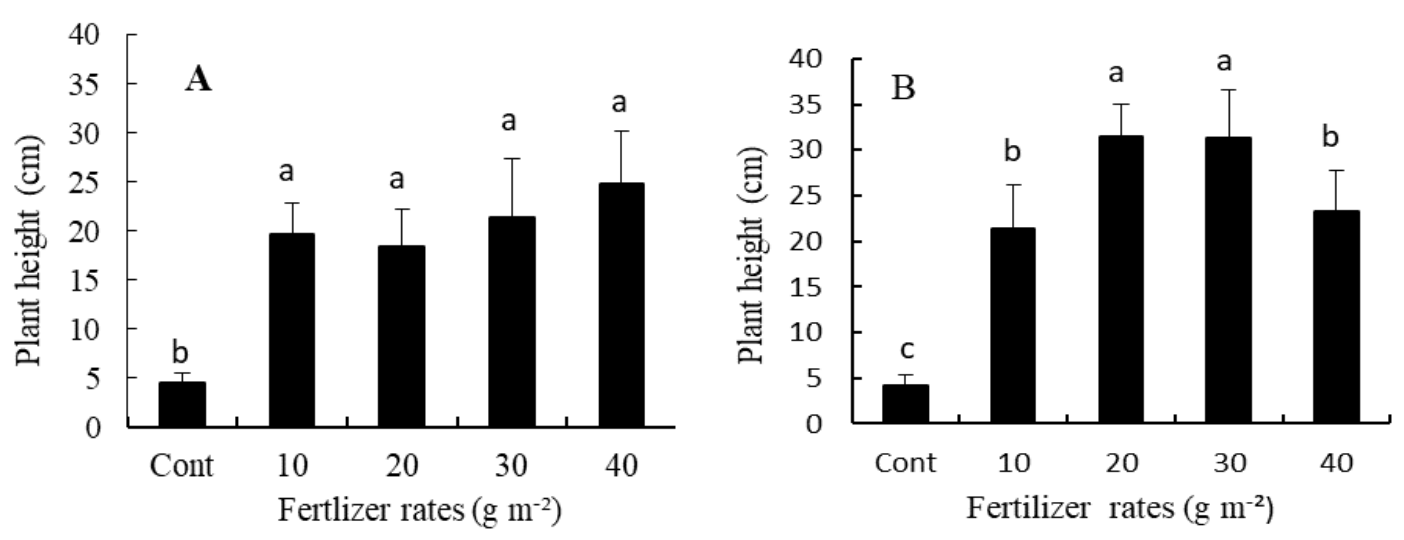

Figure 5. Effects of combined fertilizer NPK rates on plant height of amaranth lines $B B(A)$ and

$B C(B)$ cultivated from June to July, 2014. Bars with the same letter are not significantly different at the 5\% level, as determined by LSD test. Error bars represent standard deviation of the data
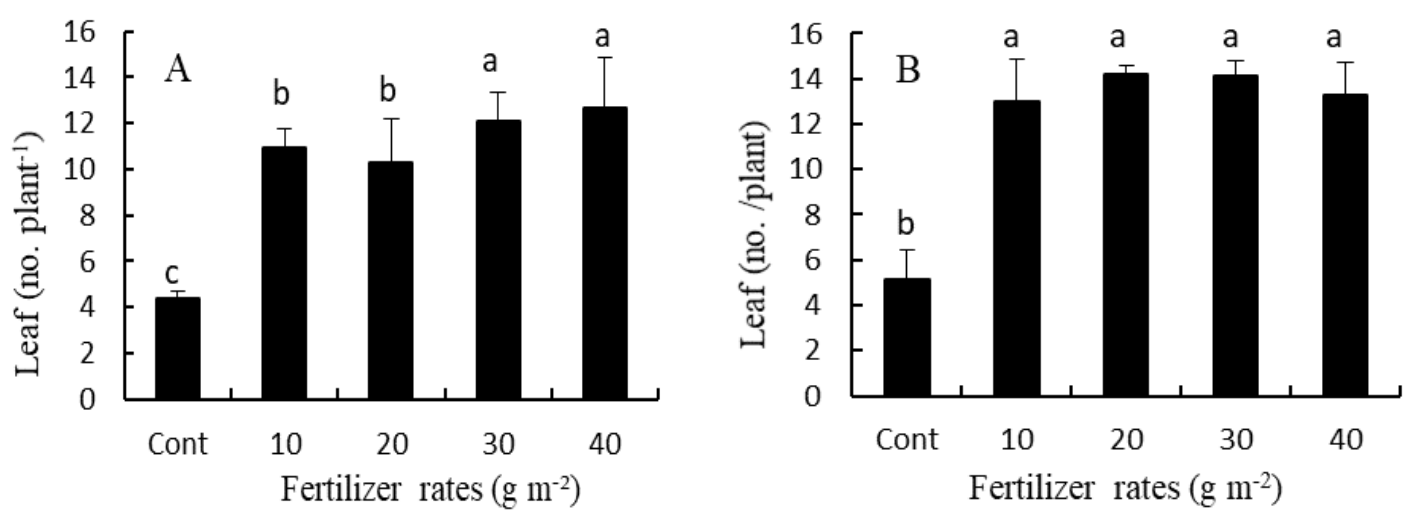

Figure 6. Effects of combined fertilizer NPK rates on leaf number of amaranth lines $B B(A)$ and

$B C(B)$ cultivated from June to July, 2014. Bars with the same letter are not significantly different at the $5 \%$ level, as determined by LSD test. Error bars represent standard deviation of the data

Stem diameter of amaranth BB line was similarly higher with the fertilizer rate of 20-40 $\mathrm{g} \mathrm{m}^{-2}$ (Table 3). Largest leaf and total leaf area were similarly highest with the $30-40 \mathrm{~g} \mathrm{~m}^{-2}$. Fresh and dry weight of leaf and stem was similarly higher with the fertilizer rate of 20-40 $\mathrm{g} \mathrm{m}^{-2}$. Fresh and dry shoot weight was highest with the $40 \mathrm{~g} \mathrm{~m}^{-2}$ followed by $30 \mathrm{~g} \mathrm{~m}^{-2}$ (Table 3).

Amaranth BC line had increased growth parameters and yield (shoot) with all the fertilizer rates (Table 3), and the growth parameters and yield were similarly higher with the fertilizer rates of $20-30 \mathrm{~g} \mathrm{~m}^{-2}$. The growth parameters and yield were found to be decreased with the fertilizer of $40 \mathrm{~g} \mathrm{~m}^{-2}$ (Table 3).

\section{Effects of fertilizer $N, P$ and $K$ applied alone and in combination on minerals, $N$ and C content of amaranths}

The Na content increased with the fertilizer P and NP and decreased with the NPK and PK (Table 2). The K content increased with all the fertilizer treatments except NP, 
which was highest with the fertilizer NPK followed by P. The Ca content increased with the fertilizer K but decreased with the fertilizer NPK and NP. The content of Mg was not influenced with the fertilizers. The P content increased with the fertilizer NPK but decreased with the $\mathrm{P}$ and NP. The $\mathrm{N}$ content was highest with the fertilizer NPK followed by NP, and C content was lower with all the fertilizers (Table 4). Data was not recorded for the fertilizer treatments of $\mathrm{N}$ and $\mathrm{NK}$ due to very poor plant growth.

Table 3. Effects of combined fertilizer NPK rates on plant growth parameter and yield (shoot) of amaranth lines BB and BC cultivated in red soil from June to July, 2014

\begin{tabular}{|c|c|c|c|c|c|c|c|c|c|}
\hline $\begin{array}{c}\text { Fertilizer } \\
\text { rates } \\
\text { Lines }\left(\mathrm{g} \mathrm{m}^{-2}\right)\end{array}$ & $\begin{array}{c}\text { Stem } \\
\text { diameter } \\
(\mathrm{mm})\end{array}$ & $\begin{array}{l}\text { Largest } \\
\text { leaf area } \\
\left(\mathrm{cm}^{2} \mathrm{leaf}^{-1}\right)\end{array}$ & $\begin{array}{c}\text { Total leaf } \\
\text { area } \\
\left(\mathrm{cm}^{2} \text { plant }^{-1}\right)\end{array}$ & $\begin{array}{c}\text { Fresh leaf } \\
\text { weight } \\
\left(\mathrm{cm}^{2} \text { plant }^{-1}\right)\end{array}$ & $\begin{array}{c}\text { Dry leaf } \\
\text { weight } \\
\left(\mathrm{cm}^{2} \text { plant }^{-1}\right)\end{array}$ & $\begin{array}{c}\begin{array}{c}\text { Fresh stem } \\
\text { weight } \\
\left(\mathrm{cm}^{2} \text { plant }^{-1}\right)\end{array} \\
\text {. }\end{array}$ & $\begin{array}{c}\text { Dry stem } \\
\text { weight } \\
\left(\mathrm{cm}^{2} \text { plant }^{-1}\right)\end{array}$ & $\begin{array}{c}\text { Fresh } \\
\text { shoot } \\
\text { weight } \\
\left(\mathrm{cm}^{2} \text { plant }^{-1}\right)\end{array}$ & $\begin{array}{c}\text { Dry shoot } \\
\text { weight } \\
\left(\mathrm{cm}^{2} \text { plant }^{-1}\right)\end{array}$ \\
\hline BB Cont & $1.28 \mathrm{c}$ & $2.08 \mathrm{c}$ & $5.61 \mathrm{~d}$ & $0.15 c$ & $0.03 \mathrm{c}$ & $0.16 \mathrm{c}$ & $0.01 \mathrm{c}$ & $0.31 \mathrm{e}$ & $0.04 d$ \\
\hline BB10 & $4.16 \mathrm{~b}$ & $22.69 b$ & $101.60 \mathrm{c}$ & $4.62 b$ & $0.61 b$ & $2.30 \mathrm{~b}$ & $0.21 b$ & $6.92 \mathrm{~d}$ & $0.82 \mathrm{c}$ \\
\hline BB20 & $5.40 \mathrm{ab}$ & $22.56 \mathrm{~b}$ & $131.39 \mathrm{~b}$ & $5.51 \mathrm{ab}$ & $0.78 \mathrm{ab}$ & $3.39 \mathrm{ab}$ & $0.35 \mathrm{a}$ & $8.90 \mathrm{c}$ & $1.13 b$ \\
\hline BB30 & $5.61 \mathrm{ab}$ & $24.37 \mathrm{ab}$ & $138.75 \mathrm{ab}$ & $6.73 a$ & $0.84 \mathrm{a}$ & $3.55 \mathrm{ab}$ & $0.38 \mathrm{a}$ & $10.28 b$ & $1.22 \mathrm{ab}$ \\
\hline BB40 & $6.01 \mathrm{a}$ & $26.70 \mathrm{a}$ & $153.19 \mathrm{a}$ & $7.58 \mathrm{a}$ & $0.97 \mathrm{a}$ & $4.54 \mathrm{a}$ & $0.41 \mathrm{a}$ & $12.12 \mathrm{a}$ & $1.38 \mathrm{a}$ \\
\hline BC Cont & $1.57 \mathrm{c}$ & $1.71 \mathrm{~d}$ & $7.54 \mathrm{~d}$ & $0.25 \mathrm{~d}$ & $0.14 \mathrm{c}$ & $0.13 \mathrm{c}$ & $0.05 \mathrm{c}$ & $0.38 \mathrm{c}$ & $0.19 \mathrm{c}$ \\
\hline $\mathrm{BC} 10$ & $4.88 \mathrm{~b}$ & $16.76 \mathrm{c}$ & $75.74 \mathrm{c}$ & $2.96 \mathrm{c}$ & $0.41 b$ & $3.48 \mathrm{~b}$ & $0.30 \mathrm{~b}$ & $6.44 b c$ & $0.72 b$ \\
\hline BC20 & $7.06 \mathrm{a}$ & $27.75 \mathrm{a}$ & $121.82 \mathrm{ab}$ & $6.55 \mathrm{a}$ & $0.58 \mathrm{a}$ & $9.22 \mathrm{a}$ & $0.50 \mathrm{a}$ & $15.77 \mathrm{a}$ & $1.07 \mathrm{a}$ \\
\hline BC30 & 6.69ab & $27.56 \mathrm{a}$ & $134.95 \mathrm{a}$ & $6.25 \mathrm{a}$ & $0.57 \mathrm{a}$ & $9.51 \mathrm{a}$ & $0.47 \mathrm{a}$ & $15.76 \mathrm{a}$ & $1.04 \mathrm{a}$ \\
\hline BC40 & $5.85 \mathrm{~b}$ & $24.44 \mathrm{~b}$ & $105.91 b$ & $4.72 b$ & $0.39 b$ & $5.36 \mathrm{~b}$ & $0.23 b$ & $10.08 \mathrm{~b}$ & $0.62 b$ \\
\hline
\end{tabular}

Data with the same letter within each column for each applied fertilizer are not significantly different at the $5 \%$ level, as determined by LSD test

Table 4. Effects of fertilizer $N, P$ and $K$ applied alone or in combination on mineral, total nitrogen and total carbon content of amaranth cultivated from November to December, 2014

\begin{tabular}{c|c|c|c|c|c|c|c|c}
\hline $\begin{array}{c}\text { Fertilizer } \\
\text { Treatment }\end{array}$ & $\begin{array}{c}\mathbf{N a} \\
\left(\mathrm{mg} \mathrm{g}^{-2}\right)\end{array}$ & $\begin{array}{c}\mathbf{K} \\
\left(\mathrm{mg} \mathrm{g}^{-2}\right)\end{array}$ & $\begin{array}{c}\mathbf{C a} \\
\left(\mathrm{mg} \mathrm{g}^{-2}\right)\end{array}$ & $\begin{array}{c}\mathbf{M g} \\
\left(\mathrm{mg} \mathrm{g}^{-2}\right)\end{array}$ & $\begin{array}{c}\mathbf{F e} \\
\left(\mathrm{mg} \mathrm{g}^{-2}\right)\end{array}$ & $\begin{array}{c}\mathbf{P} \\
\left(\mathrm{mg} \mathrm{g}^{-2}\right)\end{array}$ & $\begin{array}{c}\mathbf{T N} \\
(\%)\end{array}$ & $\begin{array}{c}\text { TC } \\
(\%)\end{array}$ \\
\hline Cont & $6.1 \mathrm{bc}$ & $61.6 \mathrm{~d}$ & $29.0 \mathrm{~b}$ & $20.5 \mathrm{a}$ & $0.70 \mathrm{ab}$ & $14.3 \mathrm{~b}$ & $2.43 \mathrm{~b}$ & $39.27 \mathrm{a}$ \\
K & $6.9 \mathrm{~b}$ & $74.3 \mathrm{c}$ & $46.6 \mathrm{a}$ & $23.9 \mathrm{a}$ & $1.01 \mathrm{a}$ & $15.2 \mathrm{~b}$ & $2.49 \mathrm{~b}$ & $37.88 \mathrm{c}$ \\
$\mathrm{P}$ & $10.4 \mathrm{a}$ & $95.6 \mathrm{~b}$ & $27.7 \mathrm{~b}$ & $25.5 \mathrm{a}$ & $0.53 \mathrm{~b}$ & $10.9 \mathrm{c}$ & $1.64 \mathrm{c}$ & $37.85 \mathrm{c}$ \\
$\mathrm{N}$ & - & - & - & - & - & - & - & - \\
NK & - & - & - & - & - & - & - & - \\
NPK & $4.5 \mathrm{c}$ & $118.2 \mathrm{a}$ & $13.7 \mathrm{~d}$ & $11.5 \mathrm{~b}$ & $0.69 \mathrm{ab}$ & $29.5 \mathrm{a}$ & $6.49 \mathrm{a}$ & $38.69 \mathrm{~b}$ \\
$\mathrm{NP}$ & $10.6 \mathrm{a}$ & $43.8 \mathrm{e}$ & $18.1 \mathrm{~cd}$ & $19.1 \mathrm{a}$ & $0.48 \mathrm{~b}$ & $3.9 \mathrm{e}$ & $3.87 \mathrm{ab}$ & $37.87 \mathrm{c}$ \\
PK & $4.3 \mathrm{c}$ & $76.3 \mathrm{c}$ & $25.6 \mathrm{bc}$ & $19.1 \mathrm{a}$ & $0.22 \mathrm{c}$ & $6.7 \mathrm{~d}$ & $1.73 \mathrm{c}$ & $37.22 \mathrm{~d}$ \\
\hline
\end{tabular}

Data with the same letter within each column for each applied fertilizer are not significantly different at the $5 \%$ level, as determined by LSD test. - data not recorded due to poor growth

\section{Effects of fertilizer NPK rates on mineral, $N$ and $C$ content of amaranths}

In the amaranth $\mathrm{BB}$ line, $\mathrm{Na}$ and $\mathrm{Ca}$ content increased with the fertilizer rate of $10-20 \mathrm{~g} \mathrm{~m}^{-2}$ and $10 \mathrm{~g} \mathrm{~m}^{-2}$, respectively (Table 5). The content of $\mathrm{K}$ and $\mathrm{Mg}$ was similarly higher with the $20-40 \mathrm{~g} \mathrm{~m}^{-2}$ and $10-30 \mathrm{~g} \mathrm{~m}^{-2}$, respectively. The content of $\mathrm{Al}$, 
$\mathrm{Fe}$ and $\mathrm{P}$ increased with all the fertilizer rates., and $\mathrm{N}$ and $\mathrm{C}$ contents were highest with the $20 \mathrm{~g} \mathrm{~m}^{-2}$. In the $\mathrm{BC}$ line, the content of $\mathrm{Na}, \mathrm{K}, \mathrm{Fe}$ and $\mathrm{P}$ increased with all the fertilizer rates, and $\mathrm{Ca}, \mathrm{Mg}$ and $\mathrm{Al}$ increased with the fertilizer at $10-30 \mathrm{~g} \mathrm{~m}^{-2}$, 20-40 $\mathrm{g} \mathrm{m}^{-2}$ and $40 \mathrm{~g} \mathrm{~m}^{-2}$, respectively (Table 5). The $\mathrm{K}, \mathrm{Mg}$ and $\mathrm{P}$ contents were highest with the $30 \mathrm{~g} \mathrm{~m}^{-2}$ followed by $40 \mathrm{~g} \mathrm{~m}^{-2}$, and Ca was highest with the $20 \mathrm{~g} \mathrm{~m}^{-2}$ followed by $30 \mathrm{~g} \mathrm{~m}^{-2}$. The Al content was highest with the $40 \mathrm{~g} \mathrm{~m}^{-2}$ followed by $30 \mathrm{~g} \mathrm{~m}^{-2}$ and $\mathrm{Fe}$ was highest with the $10 \mathrm{~g} \mathrm{~m}^{-2}$ followed by $20 \mathrm{~g} \mathrm{~m}^{-2}$. The $\mathrm{N}$ content was highest with the $40 \mathrm{~g} \mathrm{~m}^{-2}$ followed by $30 \mathrm{~g} \mathrm{~m}^{-2}$ and $\mathrm{C}$ content was highest with the $10 \mathrm{~g} \mathrm{~m}^{-2}$ followed by $20 \mathrm{~g} \mathrm{~m}^{-2}$.

Table. 5. Effects of combined fertilizer NPK rates on mineral, nitrogen and carbon content of amaranth lines BB and BC cultivated in red soil from June to July, 2014

\begin{tabular}{c|c|c|c|c|c|c|c|c|c|c}
\hline Line & $\begin{array}{c}\text { Fertilizer } \\
\text { rates }\left(\mathbf{g m}^{-2}\right)\end{array}$ & $\begin{array}{c}\mathbf{N a} \\
\left(\mathrm{mg} \mathrm{g}^{-2}\right)\end{array}$ & $\begin{array}{c}\mathbf{K} \\
\left(\mathrm{mg} \mathrm{g}^{-2}\right)\end{array}$ & $\begin{array}{c}\mathbf{C a} \\
\left(\mathrm{mg} \mathrm{g}^{-2}\right)\end{array}$ & $\begin{array}{c}\mathbf{M g} \\
\left(\mathrm{mg} \mathrm{g}^{-2}\right)\end{array}$ & $\begin{array}{c}\mathbf{A l} \\
\left(\mathrm{mg} \mathrm{g}^{-2}\right)\end{array}$ & $\begin{array}{c}\mathbf{F e} \\
\left(\mathrm{mg} \mathrm{g}^{-2}\right)\end{array}$ & $\begin{array}{c}\mathbf{P} \\
\left(\mathrm{mg} \mathrm{g}^{-2}\right)\end{array}$ & $\begin{array}{c}\text { TN } \\
(\%)\end{array}$ & $\begin{array}{c}\text { TC } \\
(\%)\end{array}$ \\
\hline \multirow{5}{*}{$\mathrm{BB}$} & Cont & $6.73 \mathrm{~b}$ & $80.16 \mathrm{c}$ & $52.48 \mathrm{~b}$ & $35.93 \mathrm{~b}$ & $0.45 \mathrm{c}$ & $0.79 \mathrm{c}$ & $22.63 \mathrm{~d}$ & - & - \\
& 10 & $7.63 \mathrm{ab}$ & $112.00 \mathrm{~b}$ & $70.53 \mathrm{a}$ & $44.36 \mathrm{a}$ & $0.53 \mathrm{~b}$ & $0.83 \mathrm{~b}$ & $31.23 \mathrm{c}$ & $2.75 \mathrm{~d}$ & $36.99 \mathrm{~b}$ \\
& 20 & $8.30 \mathrm{a}$ & $135.66 \mathrm{a}$ & $56.02 \mathrm{~b}$ & $44.25 \mathrm{a}$ & $0.56 \mathrm{a}$ & $0.81 \mathrm{bc}$ & $30.53 \mathrm{c}$ & $3.78 \mathrm{a}$ & $37.21 \mathrm{a}$ \\
& 30 & $6.83 \mathrm{~b}$ & $142.83 \mathrm{a}$ & $55.73 \mathrm{~b}$ & $41.65 \mathrm{a}$ & $0.57 \mathrm{a}$ & $0.91 \mathrm{a}$ & $44.00 \mathrm{~b}$ & $3.40 \mathrm{~b}$ & $36.93 \mathrm{~b}$ \\
& 40 & $6.86 \mathrm{~b}$ & $151.66 \mathrm{a}$ & $55.60 \mathrm{~b}$ & $36.06 \mathrm{~b}$ & $0.58 \mathrm{a}$ & $0.92 \mathrm{a}$ & $49.26 \mathrm{a}$ & $3.06 \mathrm{c}$ & $37.00 \mathrm{~b}$ \\
\hline \multirow{5}{*}{$\mathrm{BC}$} & Cont & $6.23 \mathrm{c}$ & $73.03 \mathrm{~d}$ & $36.40 \mathrm{c}$ & $36.36 \mathrm{bc}$ & $0.51 \mathrm{~b}$ & $0.68 \mathrm{~b}$ & $13.63 \mathrm{~d}$ & - & - \\
& 10 & $8.86 \mathrm{~b}$ & $117.66 \mathrm{c}$ & $43.70 \mathrm{~b}$ & $32.53 \mathrm{c}$ & $0.53 \mathrm{~b}$ & $0.90 \mathrm{a}$ & $22.13 \mathrm{c}$ & $2.23 \mathrm{~d}$ & $38.03 \mathrm{a}$ \\
& 20 & $10.90 \mathrm{a}$ & $144.33 \mathrm{~b}$ & $53.43 \mathrm{a}$ & $38.16 \mathrm{~b}$ & $0.54 \mathrm{ab}$ & $0.82 \mathrm{a}$ & $23.03 \mathrm{c}$ & $2.98 \mathrm{c}$ & $37.40 \mathrm{a}$ \\
& 30 & $10.93 \mathrm{a}$ & $188.66 \mathrm{a}$ & $48.53 \mathrm{ab}$ & $44.93 \mathrm{a}$ & $0.56 \mathrm{ab}$ & $0.74 \mathrm{~b}$ & $31.60 \mathrm{a}$ & $3.99 \mathrm{~b}$ & $37.07 \mathrm{a}$ \\
& 40 & $9.56 \mathrm{ab}$ & $175.66 \mathrm{a}$ & $37.40 \mathrm{c}$ & $44.10 \mathrm{a}$ & $0.60 \mathrm{a}$ & $0.72 \mathrm{~b}$ & $28.06 \mathrm{~b}$ & $5.07 \mathrm{a}$ & $35.73 \mathrm{~b}$ \\
\hline
\end{tabular}

Data with the same letter within each column for each applied fertilizer are not significantly different at the \% level, as determined by LSD test. - data not recorded due to insufficient sample

\section{Discussion}

The growth of amaranth was best with the fertilizer NPK followed by NP, and plant growth was very poor with the fertilizer N, P, K, NK and PK and many of the plants died (Figs. 1, 2 and 3). The fertilizer $\mathrm{N}$ and NK showed adverse effect on plant height and leaf. All the growth parameters and yield (shoot) of amaranth were highest with the fertilizer NPK followed by NP (Table 1). The fertilizer N and NK showed adverse effect on all the growth parameters and yield of the amaranth, which indicate that $\mathrm{P}$ level is not available and $\mathrm{N}$ is not effective without $\mathrm{P}$ in the red soil. The fertilizers $\mathrm{K}, \mathrm{P}$ and PK did not increase the growth parameters and yield, which indicates that amaranth plant cannot grow without combined fertilizers NP or NPK in the red soil. Similarly, several studies reported that shoot and root growth is reduced by $\mathrm{P}$ deficiency, $\mathrm{N}$ fertilizer contributes to $26-41 \%$ of crop yield, and $\mathrm{P}$ and $\mathrm{K}$ promote absorption of other nutrients and plant growth (Oya, 1972; Maier et al., 1994; Ivonyi et al., 1997; Sarker et al., 2002; Akamine et al., 2007).

Plants height of the BB line increased with all the fertilizer rates, however the fertilizer rates did not differ from each other, but they differed from the control. Plant height of the BC line did not increase with all the fertilizer rates, while it seems that a plateau was reached at 20-30 $\mathrm{g} \mathrm{m}^{-2}$ rates, then the height decreased (Fig. 5). Similarly, the leaf number of the $\mathrm{BC}$ line increased only compared to control, therefore 
determining the highest value at a certain fertilizer rate is not relevant (Fig. 6). The stem diameter and leaf area of BB line were similarly highest with the $30-40 \mathrm{~g} \mathrm{~m}^{-2}$ (Table 4). Weight of leaf and stem was similarly higher with fertilizer rates of 20-40 $\mathrm{g} \mathrm{m}^{-2}$. Fresh and dry shoot weight was highest with the $40 \mathrm{~g} \mathrm{~m}^{-2}$ followed by $30 \mathrm{~g} \mathrm{~m}^{-2}$. All the growth parameters and yield of amaranth BC line were similarly higher with the fertilizer rates of 20-30 $\mathrm{g} \mathrm{m}^{-2}$ and found to be decreased with the $40 \mathrm{~g} \mathrm{~m}^{-2}$. Similarly, Hossain et al. (2004) reported that too much fertilizer has a negative impact on Panicum repens. The amaranth BB line obtained 29\% higher shoot (yield) biomass which required higher rate of fertilizer NPK, compared to line BC (the value was calculated from the best data of each amaranth line, Table 3). Similarly, Panicum repens required increasing rate of fertilizer with the increasing shoot biomass (Hossain et al., 2004).

The Na content was lower but $\mathrm{K}$ content was highest with the fertilizer NPK (Table 2). The Ca content increased with the fertilizer K but decreased with the NPK and NP. The content of Mg was not influenced with the fertilizers. The P and $\mathrm{N}$ content in amaranth increased with the fertilizer NPK. The results indicate that a specific fertilizer does not show the same trend in the accumulation of all the minerals and $\mathrm{N}$; some minerals increased but other minerals decreased with a fertilizer element. Similar results were reported in several plants (Hossain et al., 2011; Gruber et al., 2013). It is difficult to clarify the fertilizer effects on the mineral accumulation in amaranth plants cultivated on red soil, which supported the results reported by Akamine et al. (2020).

The content of $\mathrm{Na}$ and $\mathrm{Ca}$ in amaranth $\mathrm{BB}$ increased with the fertilizer rate of $10-20 \mathrm{~g} \mathrm{~m}^{-2}$ and $10 \mathrm{~g} \mathrm{~m}^{-2}$, respectively (Table 5). The content of $\mathrm{K}, \mathrm{Mg}, \mathrm{Al}$ and $\mathrm{Fe}$ was similarly increased with the fertilizer at $20-40 \mathrm{~g} \mathrm{~m}^{-2}, 10-30 \mathrm{~g} \mathrm{~m}^{-2}, 20-40 \mathrm{~g} \mathrm{~m}^{-2}$ and $30-40 \mathrm{~g} \mathrm{~m}^{-2}$, respectively. The content of $\mathrm{N}$ was higher with the $20 \mathrm{~g} \mathrm{~m}^{-2}$. The $\mathrm{Na}$ content of amaranth $\mathrm{BC}$ line was similarly higher with the $20-40 \mathrm{~g} \mathrm{~m}^{-2}$. The $\mathrm{K}$ content was highest with the $30 \mathrm{~g} \mathrm{~m}^{-2}$ followed by $40 \mathrm{~g} \mathrm{~m}^{-2}$, and $\mathrm{Ca}$ was highest with the $20 \mathrm{~g} \mathrm{~m}^{-2}$ followed by $30 \mathrm{~g} \mathrm{~m}^{-2}$. The $\mathrm{Mg}$ and $\mathrm{P}$ content was highest with the $30 \mathrm{~g} \mathrm{~m}^{-2}$ followed by $40 \mathrm{~g} \mathrm{~m}^{-2}$, Al was highest with the $40 \mathrm{~g} \mathrm{~m}^{-2}$ followed by $30 \mathrm{~g} \mathrm{~m}^{-2}$, and $\mathrm{Fe}$ was highest with the $10 \mathrm{~g} \mathrm{~m}^{-2}$ followed by $20 \mathrm{~g} \mathrm{~m}^{-2}$. The $\mathrm{N}$ content was highest with the $40 \mathrm{~g} \mathrm{~m}^{-2}$ followed by $30 \mathrm{~g} \mathrm{~m}^{-2}$. These results indicate that mineral accumulation influenced by fertilizer rates differ with the amaranth lines, and a certain level of fertilizer NPK may be required to accumulate a particular mineral, which is similar to the results in other study (Akamine et al., 2020). In addition, it is thought that positive or negative interactions occur among the minerals and $\mathrm{N}$ existed in the soil and supplied fertilizers, which influence differently in accumulation of mineral and $\mathrm{N}$ in the amaranth plants. However, the major minerals were increased with the fertilizer rates of 20-40 $\mathrm{g} \mathrm{m}^{-2}$ in both the amaranth lines.

\section{Conclusion}

The plant cultivated with the fertilizer N, P, K, NK and PK was very poor in growth, and $\mathrm{N}$ and NK showed adverse effect. All the growth parameters and yield of amaranth were highest with the fertilizer NPK followed by NP. Growth parameters and yield were significantly higher with the fertilizer $30-40 \mathrm{~g} \mathrm{~m}^{-2}$ for the BB line, and with the 20-30 $\mathrm{g} \mathrm{m}^{-2}$ for the BC line. The fertilizer NPK resulted higher content of $\mathrm{K}, \mathrm{P}$ and $\mathrm{N}$, and lower content of $\mathrm{Na}$ and $\mathrm{Ca}$ in the amaranths. The content of $\mathrm{Na}$ and $\mathrm{Ca}$ was not influenced by the fertilizer NPK rates, whereas the content of $\mathrm{K}, \mathrm{Fe}$ and $\mathrm{Mg}$ was higher with the fertilizer $30-40 \mathrm{~g} \mathrm{~m}^{-2}$ in the amaranth BB line. The content of $\mathrm{Na}, \mathrm{K}, \mathrm{Ca}, \mathrm{Mg}, \mathrm{P}$ 
and $\mathrm{N}$ was higher with the fertilizer $30 \mathrm{~g} \mathrm{~m}^{-2}$ in the $\mathrm{BC}$ line. The results indicate that mineral accumulation differed with the fertilizer rates and amaranth lines, however major minerals increased with the fertilizer NPK rates of $20-40 \mathrm{~g} \mathrm{~m}^{-2}$. The results indicate that $\mathrm{P}$ level was not available, $\mathrm{N}$ was not effective without $\mathrm{P}$, amaranth plant could not grow without combined fertilizers NP or NPK, and mineral contents in the amaranths did not differ clearly with the individual or combined fertilizers in the red soil. Above results suggest that fertilizer NPK at 30-40 $\mathrm{g} \mathrm{m}^{-2}$ is effective for higher yield and quality of amaranth in the red soil of Okinawa. However, it was not possible to evaluate clear effects of fertilizer N, P and K on yield and quality of amaranth in this soil. Therefore, more detailed experiments should be conducted considering the physical and chemical properties of the red soil to clarify the actual effects of individual and combined fertilizers of $\mathrm{N}, \mathrm{P}$ and $\mathrm{K}$ on yield and mineral content of different amaranth cultivars.

Acknowledgements. We are thankful to the technical staffs of CRAC, University of the Ryukyus for supporting chemical analysis.

Conflicts of interests. The authors declare no conflict of interests.

\section{REFERENCES}

[1] Abbott, J. A., Campbell, T. A. (1982): Sensory evaluation of vegetable amaranth (Amaranthus spp.). - HortScience 17: 409-410.

[2] Adegbola, P. I., Adetutu, A., Olaniyi, T. D. (2020): Antioxidant activity of Amaranthus species from the Amaranthaceae family - a review. - South African Journal of Botany 133: 111-117.

[3] Akamine, H., Hossain, M. A., Ishimine, Y., Yogi, K., Hokama, K., Iraha, Y., Aniya, Y. (2007): Effects of application of N, P and K alone or combination on growth, yield and curcumin content of turmeric (Curcuma long L.). - Plant Production Science 10: 151154.

[4] Akamine, H., Ohshiro, M., Hossain, M. A. (2020): Fertilizer management for amaranth (Amaranthus spp.) cultivation on dark-red soil in Okinawa, Jaapan. - Applied Ecology and Environmental Research 18(6): 8145-8158.

[5] Chowdhury, R. H., Rahman, G. M. M., Saha, B. K., Chowdhury, A. H. (2008): Addition of some tree leaf litters in forest soil and their effect on the growth, yield and nutrient uptake by red amaranth. - Journal of Agroforestry and Environment 2: 1-6.

[6] Dasgupta, N., De, B. (2007): Antioxidant activity of some leafy vegetables in India: A comparative study. - Food Chemistry 101: 471-474.

[7] Dewan, M. N. N., Haq, M. E., Hasan, M. M., Hossain, M. S., Tareq, M. Z. (2017): Genotype X Environment interaction effects on the field performance of stem amaranth (Amaranthus tricolor L.). - Bangladesh J. Pl. Breed. Genet. 30: 21-31.

[8] Gruber, B. D., Giehl, R. F. H., Friedel, S., Wiren, N. V. (2013): Plasticity of the arabidopsis root system under nutrient deficiencies. - Plant Physiology 163: 161-179.

[9] Hossain, M. A., Ishimine, Y., Akamine, H., Kuramochi, H. (2004): Effect of nitrogen fertilizer application on growth, biomass production and N-uptake of torpedograss (Panicum repens L.). - Weed Biology and Management 4: 86-94.

[10] Hossain, M. A., Ishimine, Y. (2005): Growth, yield and quality of turmeric (Curcuma longa L.) cultivated on dark-red soil, gray soil and red soil in Okinawa, Japan. - Plant production Science 8: 482-486. 
[11] Hossain, M. A., Yamanishi, M., Yara, T., Chibana, S., Tamaki, M. (2011): Growth characteristics, yield and mineral content of redflower ragleaf (Crassocephalum crepidioides(Benth.)S.Moore) at different growth stages, and in dark-red soil, red soil and gray soil in Okinawa. - Science Bulletin, Faculty of Agriculture, University of the Ryukyus 58: 1-11.

[12] Hossain, M. A., Akamine, H., Nakamura, I., Tamaki, M. (2012): Effects of N, P and K on growth characteristics of redflower ragleaf (Crassocephalum crepidioides). - Science Bulletin, Faculty of Agriculture, University of the Ryukyus 59: 13-18.

[13] Ivonyi, I., Izsoki, Z., Van der Werf, H. M. G. (1997): Influence of nitrogen supply and P and $\mathrm{K}$ levels of the soil on dry matter and nutrient accumulation of fiber helm (Cannabis sativa L.). - Journal of the International Hemp Association 4: 82-87.

[14] Khandaker, L., Ali, M. B., Oba, S. (2008): Total polyphenol and antioxidant activity of red amaranth (Amaranthus tricolor L.) as affected by different sunlight level. - Journal of the Japanese Society for Horticultural Science 77: 395-401.

[15] Longato, E., Meineri, G., Peiretti, P. G. (2017): The effect of Amaranthus caudatus supplementation to diets containing linseed oil on oxidative status, blood serum metabolites, growth performance and meat quality characteristics in broilers. - Animal Science Papers and Reports 35: 71-86.

[16] Maier, N. A., Barth, G. E., Bennell, M. (1994): Effect of nitrogen, potassium and phosphorus on the yield, growth and nutrient status of ixodia daisy (Ixodia achillaeiodes ssp. Alata). - Australian Journal of Experimental Agriculture 34: 681-689.

[17] Maurya, N. K., Arya, P. (2018): Amaranthus grain nutritional benefits: A review. Journal of Pharmacognosy and Phytochemistry 7: 2258-2262.

[18] Nakano, H., Morita, S. (2009): Effects of planting time and nitrogen application on dry matter yield of the forage rice cultivar tachiaoba in southwestern Japan. - Plant Production Science 12: 351-358.

[19] Ohshiro, M., Akamine, H., Hossain, M. A., Nakamura, I., Tamaki, M., Nose, A. (2015): Growth characteristics, yield and quality of some vegetable amaranths (Amaranthus spp.) cultivated in Okinawa, Japan. - Japanese Crop Science Society 84: 69-77.

[20] Ohshiro, M., Hossain, M. A., Nakamura, I., Akamine, H., Tamaki, M., Bhowmik, P. C., Nose, A. (2016): Effects of soil types and fertilizers on growth, yield and quality of edible Amaranthus tricolor lines in Okinawa, Japan. - Plant Production Science 19: 61-72.

[21] Oya, K. (1972): Evaluation of potassium availability of four Michigan soils. - Science Bulletin, Faculty of Agriculture, University of the Ryukyus 19: 123-257.

[22] Prakash, D., Pal, M. (1991): Nutritional and anti-nutritional composition of vegetables and grain amaranth leaves. - Journal of the Science of Food and Agriculture 57: 573-583.

[23] Rastogi, A., Shukla, S. (2013): Amaranth: a new millennium crop of nutraceutical value. - Critical Reviews in Food Science and Nutrition 53: 109-125.

[24] Sarker, M. A. Z., Murayama, S., Akamine, H., Nakamura, I. (2002): Effect of nitrogen fertilization on photosynthetic characteristics and dry matter production in F1 hybrids of rice (Oryza sativa L.). - Plant Production Science 5: 131-138.

[25] Shimray, A. G., Sarma, P., Anal, P. M., Debnath, P., Singh, S. R., Kharga, S., Semba, S. (2019): Effect of spacing and nutrient management on growth and yield of king chilli (Capsicum chinense Jacq.) grown under protected condition. - International Journal of Current Microbiology and Applied Sciences 8: 2761-2770.

[26] Shittu, O. S., Adebooye, O. C., Fasina, A. S., Omolayo, F. O. (2006): Responses of leaf yield and chemical composition of Amaranthus cruentus L. and Celosia argentea L. to land use types and fertilizer regimes. - International Journal of Agricultural Research 1: 286-292.

[27] Shukla, S., Bhargawa, A., Chatterjee, A., Pandey, A. C., Mishra, B. (2010): Diversity in phenotypic and nutritional traits in vegetable amaranth (Amaranthus tricolor), a nutritionally underutilized crop. - Journal of the Science of Food and Agriculture 90: 139-144. 
[28] Singh, B. P., Whitehead, W. F. (1996): Management methods for producing vegetable amaranth. - In: Janick, J. (ed.) Progress in new crops. ASHS Press, Arlington, pp. 511515 .

[29] Skwaryo-Bednarz, B., Brodowska, M. S., Brodowski, R. (2011): Evaluating the influence of varied NPK fertilization on yielding and microelement contents at amaranth (Amaranthus cruentus L.) depending on its cultivar and plant spacing. - Acta Scientiarum Polonorum-Hortorum Cultus 10: 245-261.

[30] Soriano-García, M., Arias-Olguín, I. I., Montes, J. P. C., Ramírez, D. G. R., Figueroa, J. S. M., Valverde, E. F., Valladares-Rodríguez, M. R. (2018): Nutritional functional value and therapeutic utilization of amaranth. - Journal of Analytical \& Pharmaceutical Research 7: 596-600.

[31] Sreelathakumary, I., Peter, K. V. (1993): Amaranth-Amaranthus spp. - In: Kalloo, G., Bergh, B. O. (eds.) Genetic improvement of vegetable crop. Pergamon, Oxford, pp. 315323.

[32] Stallknecht, G. F., Schulz-Schaeffer, J. R. (1993): Amaranth rediscovered. - In: Janick, J., Simon, J. E. (eds.) New crops. Wiley, New York, pp. 211-218.

[33] Svirskis, A. (2003): Investigation of amaranth cultivation and utilization in Lithuania. Agronomy Research 1: 253-264. 